\title{
東洋医学の生命観からみた鍼炎医学の 特徴について
}

\author{
矢 野 忠*
}

要旨 今，あらゆる分野において機械論的パラダイムに基づく合理的 な科学主義の限界が指摘されている。その限界性を越える視点として 生命論的なパラダイムが注目されている。それは医学の分野において も同様で生命的パラダイムに基づく「医学の質」が問われている。

東洋医学の生命観は, 本来的に生命論的パラダイムに基づくもので ある。特に鍼炎医学は「心身一如」の身体観に基づく無薬物療法であ ク，その治療原理は自然治癒力の賦活にある。そこには病人を中心と した全人的医療が展開され，「ケアの医学」が実践されている。

このような特徵をもつ鍼尒医学は「人にやさしい医学」として極め て魅力的であり，次代を担う新しい医学として期待される。

\section{I はじめに}

最近，「地球にやさしいエルネギー」「人にやさ しい政治」「人にやさしい医学」など「やさしい」 という言葉をよく耳にする。それは「やさしさ」 を失ったことへの深い反省の中から生まれた言葉 であろうか。

「やさしさ」とは，一言でいってしまえば相手を 思いやるということである。したがって失った「や さしさ」を取り戻そうとすれば相手の存在を尊重 し，相手との関係を重視する考え方に立つことが 大切である。

それには新たな視点へと転換をはからなければ ならない。例えば「他者としての世界」から「自 己を含む世界」への視点の転換 ${ }^{1)}$ である。

本論では,「地球にやさしい鍼炎をめざして」(第 44 回全日本銊尒学術大会, シンポジウム, 1995.) というテーマを「人にやさしい鍼炎」と読み替え， 東洋医学の生命観を軸として鍼尒医学の人への“や

* Tadashi YANO 明治銊炎大学第一東洋医学臨床教室

Key Words : 鍼炎医学, 東洋医学, ケア, 生命論, 機械論
さしさ”について検討を試みつつ，21世紀の医療 における銊炎医学の役割について展望してみた。

\section{II「知」の転換}

近代から現代まで，人類社会を支えてきたパラ ダイムは合理的な科学主義であった。この合理的 科学主義は「機械論的世界観」と「要素還元主義」 によって特徵づけられる。すなわち，世界はいか に複雑であろうと一つの巨大な機械であると捉え， 機械を要素に分析し，それらを再び統合すること によって世界のメカニズムを理解することができ るとした。そして，人類社会はこの合理的科学主 義によって驚異的な科学文明を築いた。

合理的科学主義は，今もなお各種の科学分野で 依然として有効な「知」のパラダイムとして機能 している。この「知」のパラダイムは一般に機械 論的パラダイムと呼ばれている。しかし，万能と 考えられた機械論的パラダイムによる科学的手法 にも限界性が指摘されるようになってきた。

人類はかつて経験したことのない未曽有の問題

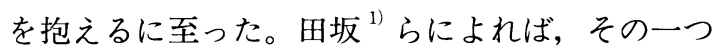
が地球規模の諸問題 (グローバル・プロブレム：環 
境污染，食糧不足，資源枯渇，人口爆発といった 諸問題)であり，もう一つが成熟社会の諸問題(フ ロンティア・プロブレム：価值観の多様化とそれ に伴う社会における意志決定の困難性，社会的受 容の困難性など)である。そしてこれらの諸問題は もはや科学技術の開発だけでは解決できないほど 深刻化しており，しかも政治，経済，文化などと も梁く関連し，複雑化している。

したがって，これらの諸問題を解決するには要 素還元主義的なアプローチでは限界があり，むし ろ学際的，全包括的にアプローチすることが必要 であるとし，そのための新たなるパラダイムを創 造しなければならないと指摘している。

そのパラダイムとは，相手を尊重し，相互の関 係性を重視する“やさしさ”の眼差しをもった思 想と理論である。それは田坂 ${ }^{1)} の 「$ 生命論パラダ

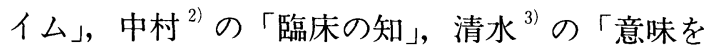
創出する関係科学」, 石川 ${ }^{4)}$ の「生命思考」などで あるが，根底においてそれらに共通する視点は生 命論的なパラダイムの視点である。

では田坂 ${ }^{1)}$ の生命論的パラダイムとは，具体的 にどのような視点を指すのか。この点について田 坂は図 1 で示すような様々な「知」の視点の転換 を挙げている。それは世界を「巨大な機械」と見 る機械論的世界観から，世界を「大いなる生命体」

\section{梘点の较换}

\begin{tabular}{|c|c|c|c|}
\hline \multirow{8}{*}{$\begin{array}{l}\text { 機 } \\
\text { 械 } \\
\text { 諯 } \\
\text { 的 } \\
\text { パ } \\
\text { ラ } \\
\text { タ } \\
\text { イ } \\
\text { 厶 } \\
\text { の } \\
\text { 視 } \\
\text { 点 }\end{array}$} & 機棫論的世界篗 & 生命的世界観 & \\
\hline & 静的な践造 & 動的なプロセス & 命 \\
\hline & 設計・制御 & 自己䢸撒化 & 的 \\
\hline & 要素嘾元主舱 & 全包括主義 & ラ \\
\hline & フォーカスの視点 & エコロジカルな視点 & 1 \\
\hline & 他者としての世界 & 自己を含む世界 & ब \\
\hline & 性能・効率による評価 & 意味・価値による倸価 & 点 \\
\hline & 言語による知の伝達 & 非言語による知の伝達 & \\
\hline
\end{tabular}

（田坂広志による）

図 1 機械論的パラダイムの視点から生命論的 パラダイムの視点への転換

田坂 ${ }^{1)}$ は現代の様々な問題を解決するには機 械論的パラダイムの視点では限界があるとし， 生命論的パラダイムの視点の重要性を指摘し ている。

とみる生命論的世界観への視点の転換である。具 体的には「要素還元主義」から「全包括主義」へ, 「設計・制御」から「自己組織化」へ，「他者とし ての世界」から「自己を含む世界」へなどの視点 の転換で特徴づけられるとしている。

また, 中村 ${ }^{2)}$ は「科学の知」から「臨床の知」へ の転換として「普遍主義(科学的宇宙観)」から「コ スモロジィー(有機的宇宙観)」へ，「論理主義 (一 義的)」から「シンボリズム (多様性・多義性 $) 」$ へ，「客観主義(一方的）」から「パフォーマンス（身 体的相互行為)」を挙げている(図 2 )。

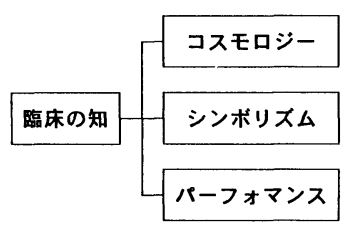

中村雄一郎氏の「臨床の知」 ${ }^{2)} よ り$ 整理した。

\section{III 東洋医学の生命観}

東洋医学の生命観は, 生命論的パラダイムと類 似した視点を有している。というよりはむしろ東 洋医学の生命観そのものが生命論的パラダイムと みなすことができるであろうし，生命論的パラダ イムの「知」の視点の原初は東洋思想(東洋医学も 含む)にあったともいえよう。

\section{1. 自然と共に}

図 3 は筆者が東洋医学の生命観における視点と 生命論的パラダイムの視点とを対応させたもので ある。

東洋医学では，人間は「自然と共に」あること を基本とし，しかも常に時間とともに変化する状 態を重視している。人間と自然との関係を「人と 天地とは相応ず」(『邪客篇』) と捉之，天の気と地 の気が出会う気交の中で人間は生かされていると している。すなわち人間と自然との関係を開放系 (Open System)の視点から論じている。そして両 者の望ましい在り方として例えば『四気調神大論 


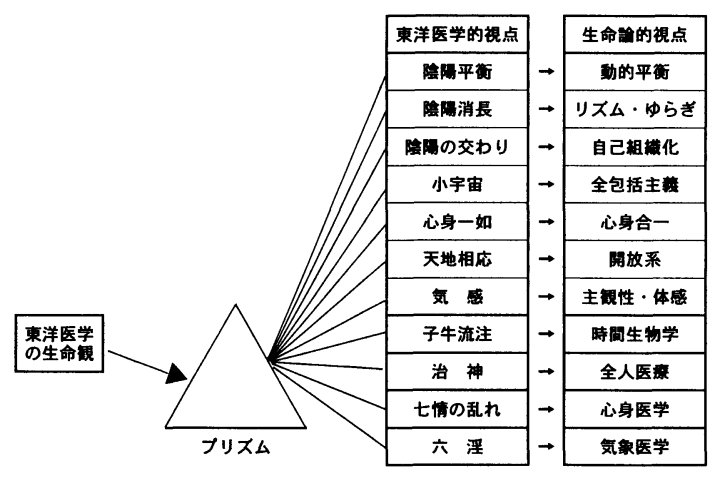

図3東洋医学の生命観にみる生命論的枠組み （あるいは視点）

東洋医学の生命観には種々の生命論的パラダ イムの視点が渾然として溶け込んでいる。こ れをプリズムで分光してみた。

篇』に見られるように季節に応じた生き方(養生法) を展開している。さらに『順気一日分為四時篇』 では病状は時間によって変化することを述べてい る。東洋医学では，陰陽消長の原理によって人間 は時間と共に変動することを深く認識しており， 時間の流れを診断・治療に応用する子牛流注 ${ }^{8)}$ と して発展した。

このような東洋医学の視点は清水 ${ }^{9,10)}$ のいう「生 きている自然」「生きている状態」を重視する視点 であり,「生きている自然が与えてくれる条件によ って人間は生かされている」 ${ }^{10)}$ との認識が根底に流 れている。この認識の中に図 3 で示した東洋医学 の生命観の視点が渾然一体となって息づいている。

また, 東洋医学の生命観の視点は, 現代科学に おける総合科学としていかされている。例えば陰 陽消長の原理は時間生物学 (Chronobiology)とし て，子牛流注は時間治療学 (Chronotherapy) とし て, 『四気調神大論篇』の一部は生気象学 (Biometeology) として発展している。

ルネ・デュボス ${ }^{11)}$ は「現代の科学の流行はとも かくとして, 生命のもっとも重要な問題が, 遺伝 子とその構造単位，あるいはそれらが支配する化 学反応の見地から生命を解析することにあると信 じる理由はなにもない。はるかに重要なことは, 生物と環境全体との複雑な相互関係にあると主張 してよいであろう。」と述べ, 現代生物学の在り方 を批判し，生物と環境との関連性を解明すること
の重要性を主張としている。

時間治療学も生気象学も個体と環境との関連性 を重視する視点に立った新しい学問分野であり, 分析に対する総合の科学としてこれからの発展が 期待されているが, その原初においては東洋医学 の基本的な生命観の視点であった。

\section{2. 心身一如としての身体}

東洋医学では五精(魂・神・意・魄・志)あるい は五情（怒・喜・思・憂・恐）といった精神活動は 五藏にあるとしている。すなわち五精・五情(精神 活動) は五藏(身体)に溶け込んでいるとの認識であ ク, 東洋医学は心身一如としての身体観を特徵と している。

特に銊尒医学の診断・治療の基本は, 身体の様及 な所見を通して心身の状態を把握し，銊と炎を用 いて身体にアプローチする。例えば抑麓状態とい う極めて精神的な病状に対する治療であっても肝 経にアプローチするように身体に㗢きかけること を旨とする。

このように東洋医学の身体観は「心身一如」と して，また市川 ${ }^{12)}$ のいう「精神としての身体，身 体としての精神」といった視点であり，このこと によってはじめて病人それぞれに適した個別的な 診療が展開できるものと考之る。すなわち全人的 医療の視点が東洋医学の基本であった。

\section{3．気流れるシステムとしての身体}

「心身一如」としての身体は，さらに臓腑経絡系 というエネルギー伝達系によって一個の有機体に 構成されている。この臓腑経絡系においては, 肝 の臓と肝経とが一つの機能ユニットとして在るよ うに, 12 の機能ユニット(臓腑経絡)がそれぞれ独 自の機能をもちながらも相生と相剋によって全体 の秩序を維持調節している。

すなわち東洋医学においては内包された制御機 構を明確に構想し，人体はシステムをもった有機 体として認識していたことがうかがえる。もちろ ん，システム全体の秩序維持は「気」という情報 によって行なわれるとするが，より安定した内部 秩序を形成するために外界との情報交流(気の交流) を重視する点に東洋医学のシステム論としての夕゙ 
イナミズムがある。

この臓腑経絡系システムは清水 ${ }^{10)}$ の提唱したバ イオホロニズムの考之方に類似している。清水 ${ }^{9,10)}$ は生命の本質に迫るには「生きている状態」をよ り梁く理解することが重要であると指摘し, バイ オホロニズムの考え方を提唱した。バイオホロニ ズムの特徴は「生きているシステム」の要素であ る「ホロン」の性質にある。清水のいう「ホロン」

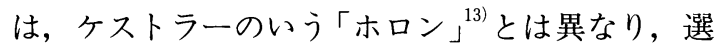
択的な内部状態をもつ協力的な要素と捉え, 要素 としての「ホロン」は全体における秩序形成に自 主的に参加するとした。同時に「全体」の秩序に よって「ホロン」は影響されるとし，「全体」と「ホ ロン」はフイードバックのループを形成し，この ループが回転することによって，再度自己組織化 による秩序が形成(新しい秩序も含む)されるとし た。当然，そこには「全体」に参加する「ホロン」 の自主的選択性による「ゆらぎ」が生じるが，こ の「ゆらぎ」は柔らかい安定した秩序を形成する 特徵となる。

東洋医学におけるシステム論については，これ からの研究課題であるが，そこには清水の指摘す る「生きている状態」を特徵づける「自己組織化」 と「ゆらぎ」の概念は十分含まれているものと考 える。しかも「陰陽平衡」と「陰陽消長」の原理 による時間を重視した柔らかいシステムとして認 識していたことは東洋医学におけるシステム論の 特徴といえるであろう。

\section{IV 人にやさしい鍼炎医学}

これからは生命論的なパラダイムの視点が必要 であると述べた。そこには「共生」の思想があり， 「やさしさ」の眼差しがある。

東洋医学の生命観はその根本に生命論的パラダ イムの視点を渾然として内包しているが，特に鍼 负医学は無薬物療法として自然治癒力を治療原理 とするだけに，マイルドでノにやさしい医学」と しての要件を満たしているものと考える。

\section{1．自然治癒力を重視する鍼炎医学}

鍼炎医学の治療原理は薬を用いず，鍼と炎とい う微細な物理的エネルギーを体表の特定部位に作
用させ，生体の自然治痛力を賦活するところにあ る。しかも生体の自然治癒力を最大限に発揮させ るために人間そのものにアプローチすることを旨 とする。治療の要諦は「治神」年)にあると指摘され ているように，良好な治療者・患者関係を背景と して鍼炎技術が展開される。

もち万ん銊尒技術は生体の反応を強制的に操作 することを意四するものではなく，生体の主体性 (治療力)にまかせると言った，極めてマイルドな 方法を取る。ただし，生体の主体性にまかせると いっても, 病的な状態においては主体性の発動が 明確に発現できるように支援しなければならない。 それが虚証に対する補法であり，実証に対する瀉 法である。すなわち，生体に内在する治癒システ ムが本来の機能を発揮できるように鍼炎技術で援 助するところに鍼炎医学の治療の特徵がある。

また，鍼尒医学の診察法では，身体は臟器によ って構成された肉体ではなく，精神が可視された 身体，独自性をもった主体的な身体であると捉え る。したがって四診情報にみられる種々の身体所 見から心身の状態を把握し, 病人の理解 (病苦)に 迫ろうとする。四診法は病人を理解するための手 立てであると考える。そして，治療においては「主 体的な身体」「精神が可視化された身体」に働きか け，不快な症状を軽減することによって，正常な 身体感覚を取り戻し，統合された人間性を回復さ せようとする。

\section{2．「体感」を重視する鍼尒医学}

高橋 ${ }^{15)}$ は，高い健康を実現するには「心地よさ の発見」が大切であるとし，「心地よさが最良の生 き方である」と述べている。そして「心地よさ」の 第一の質として一体感を挙げている。一体感とは, 自分の体を受け入れている感覚であり, 自分の体 を本当に自分のものであると感じること(現在感) であるとし，これは体の軽さによって生ずるもの であると述べている。この高橋の観点は「体感」の 重要性を指摘したものである。

筆者も銊尒治療の非特異的効果を体感の視点か ら捉えようと幾つかの研究を行なった。明治鍼炎 大学附属鍼尒センターに通院する患者 212 名の鍼 炎治療後の気分変化を「気分チェックリス卜」で 
調査したところ $80 \%$ 前後の患者は治療後,「心地 よい」気分になっていたことがわかった ${ }^{16)}$ 。また， 刺銊の心地よさを脳波トボグラフフィ一法で検討 したところ $\alpha$ 帯域の増大が認められ，刺鍼による リラクセーション効果が確認された ${ }^{17)}$ 。

このように銊尒治療は「快の医学」としての要 素を持っている。鍼炎治療は軽やかで爽快な体感 を呼び起こさせ，「よい気分」に誘導する。「よい 気分」は高い健康感と結びついた感情であるだけ に銊尒医学の治療効果上の重要な要素であると考 える。

これまでの治療はどちらかといえば苦痛を伴う ことが多かった。患者を英語で patient というが, patient とは, その語源からいって耐えるというこ とであり，診断・治療に耐えてこそ患者たりえた。 しかし, 治痛困難な慢性疾患や心身の歪みによる 疾患では必ずしも耐える治療が適切であるとは言 えず，患者が楽しむ治療あるいは快適な治療が有 効だとされている ${ }^{18)}$ 。それがアメニティ・メディス ン (amenity medicine)である。

鍼炎医学はアメニティ・メディスンの多分に要素 を持っている。これからの医療にアメニティの概 念が導入されることは確実であろうし ${ }^{19)}, 21$ 世紀 の医療を展望したとき銊尒医学がもつアメニティ 性は大きな役割を果たすことができるものと考え る。

\section{3.「触れる」ことを重視する鍼炎医学}

本来，医学とは病人を癒すためのものであり, 医学的知識や医療技術はすべて病人を救うための ものであった。しかるに現在の医学は医科学 (Medical Science)の色彩が強い。

医学における医科学の先鋭化は「キュア(Cure) の医学」を尊重し,「ケア (Care)の医学」を軽んず る医学の価值体系を形成してきた。しかし，キュ アの医学は医療環境の変化によって変わらざるを 得なくなってきた。その大きな要因は成人病など の慢性疾患の増加による疾病構造の変化である。 このような疾病構造の変化は, キュアよりはケア を必要とし, 疾病を対象とするよりは病人を診る ことを迫っている。

では「ケアの医学」とは, どのような医学を指
しているのか。端的に言えば血液生化学的な検査 データの背後に潜む病人の人生にも眼を向けてく れる医学であり，誰のものでもない「私の身体」を 診てくれる医学である ${ }^{20)}$ 。

ケアはその目的によって perinatal care(生), elder care(老), primary care(病), terminal care (死)に分けられるが，その根本は holistic care で あり，pastoral careでなければならない(図4)。

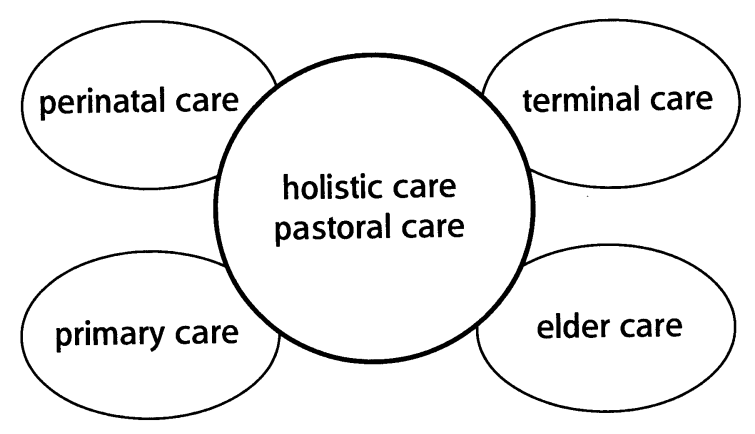

図4 ケアの医学

ケアにはその目的によって各種のケアがあるが, その根本は holistic care であり postoral care で ある。

そしてケアリングにおいては「共感」と「思いや ク」が大切であるとし，「共感が眼であるならば, 思いやりは手である」このような観点からは池辺 ${ }^{20)}$ は, ケアは肌の温かみのある手仕事であると述べ ている。

銊炎治療をはじめとする手技療法はまさに肌の 温もりを感じさせる手仕事の治療である。そこに は痒いところに手が届くような配慮が常にあり, 心がそのまま手となっている。手は「手そのもの

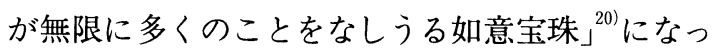
て多く癒し得る。それは古来から言われてきた「医 療の原点は手当てである」に通ずる。手がケアの 出発点であるならば鍼尒医学は「ケアの医学」で あるといっても過言ではなかろう。

\section{VI さいごに}

平成 7 年度版の厚生白書 ${ }^{21)}$ には，これからの医 療の中心は「質」であると指摘されているように， 「ケアの医学」の重要性が認識されてきた。それに は疾病構造の変化とともに高秢社会における老人 
医療の問題が背景となっているが，底流には今日 の医学を支えてきた機械論的パラダイムの行き詰 まりがある。

それは医学の分野だけの問題ではなく, 政治, 経済をはじめとするあらゆる分野においてそうで あり，各分野に共通した問題を解決するために新 たなパラダイムが求められはじめた。それは社会 現象的には様々な分野における「やさしさ」への 回帰の表現であり，思想的には東洋思想を視野に 入れた生命論的なパラダイムの提唱である。

筆者は「やさしさ」の根源を東洋医学の生命観 の視点に置き, その視点から銊尒医学の特徴につ いて述べてみた。鍼炎医学は本質的に「ケアの医 学」であり,「人にやさしい医学」である。そして 機械論的なパラダイムに変わるものとして新たに 提唱された生命論的パラダイムの視点を内包して いる。その意味において鍼尒医学は次代を担う医 学として極めて魅力的であり, 新しい医学の創造 を推し進める基盤にもなり得るものと考える。

\section{謝 辞}

第 44 回全日本鍼炎学術総会のシンポジウムで発表の 機会を与えて下さいました大会会長 弓削先生ならびに 座長の労をお取り下さいました時本先生, 真鍋先生に 対し，心より感謝の意を表します。また，明治銊尒大 学大学院教授 森 和先生より貴重な助言を賜りまし た。ここに深甚の謝意を表します。

\section{参考論文}

1）田坂広志：21 世紀の知の潮流「生命論パラダイ ム」, 生命論パラダイムの時代, 日本総合研究所 編, ダイヤモンド社, 東京(1993), pp 1〜65.

2) 中村雄一郎: 臨床の知とは何か, 岩波新書, (1992).

3）清水 博: 生命と場所, 意味を創出する関係科 学, NTT 出版, (1992).

4）石川光男: 生命思考, ニューサイエンスと東洋 思想の融合, TBS ブリタニカ, (1986).

5）小曽户丈夫, 浜田善利：意釈黄帝内経霊枢, 築 地書館, 東京 (1971), pp 232 237.

6）小曾戸丈夫, 浜田善利 : 意釈黄帝内経素問, 築 地書館, 東京 (1971), pp 15 17.

7）小曽戸丈夫, 浜田善利 : 意釈黄帝内経霊枢, 築 地書館, 東京 (1971), pp 153 155.
8）川井正久, 王永鋝：針尒時間治療学一子午流注 法一, 谷口書店, 東京 (1989).

9）清水 博：生命を捉えなおす，生きている状態 とは何か, 中央新書, 東京(1987).

10）清水 博: ホロンとしての人間, ミクロコスモ スへの挑戦, 石井威望, 小林 登, 清水 博, 村上陽 一郎編集, 中山書店, 東京(1984), pp 29 80.

11）ルネ・デュボス：人間であるために, みすず書 房, 東京 $(1970)$.

12）市川 浩：精神としての身体, 講談社学術文庫, 講談社, 東京 $(1992)$.

13）アーサ・ケストラー：機械の中の幽霊, 日高敏 隆,長野 敬訳, ペりかん社, 東京(1969).

14）小曽戸丈夫, 浜田善利 : 意釈黄帝内経素問, 築 地書館, 東京 $(1971), 112 \sim 114$.

15）高橋和巳：心地よさの発見, 三五館, 東京 (1993).

16）矢野 忠：ストレスイからの解放そして銊炎, 全日本銊尒学会誌 $43 ; 143 \sim 153$. (1993)

17）矢野 忠, 丸山彰貞, 田中敦子ら：鍼通電, TENSによる EEG トポグラムの変化, 明治鍼炎 医学 創刊号;55～64. (1985)

18）永田勝太郎：QOL, 講談社, 東京 (1992), pp 70 $\sim 92$.

19）厚生省編：厚生白書,平成 7 年度版；pp 23～33. (1995)

20）池辺義教：ケアの本性, 哲学と医療, 中川米造 編集責任, 弘文堂, 東京 (1994), pp 29～55.

21）厚生省編：厚生白書,平成 7 年度版; pp 4 14. (1995) (干 629-03 京都府船井郡日吉町 明治鍼尒大学) 


\title{
Characterlistics of Acupuncture and Moxibustion Reviewed from The Perspective of Oriental Medicine
}

\author{
Tadashi Yano \\ Meiji College of Oriental Medicine, \\ Department of first Clinic of Oriental Medicine.
}

The limitations of science based on a mechanistic paradigm has been noted in various fields such as politics, economy, science and so on. A paradigm based on organicism is worth considering instead of the mechanistic paradigm.

In the field of medicine, as in other fields, the quality of medicine has required perspective based on organicism.

The organicism of oriental medicine was origenally based on a paradigm of organicism. Especially acupuncture and moxibustion are unique therapies in which the therapy is based on the concept that mind and body unite a single entity, and the principle of therapy is the activation of the natutal healing power using acupuncture needles and moxa. In acupuncture and moxibustion medicine based on organicism, holistic medicine is performed from the perspective of treating the whole patient.

Practicing acupuncture and moxibustion with these considerations is a fascinating medicine for human being and it is a hopeful new medicine for the next generation.

Key Words: Acupuncture and Moxibustion Medicine, Oriental Medicine, Care, Organicism, Mechanism 